\title{
In search of the Holy Presence of the Blessed Mary in Tolkien's Middle-earth
}

\author{
Farid Mohammadi \\ English Department \\ Islamic Azad University, Karaj Branch \\ 31485, Karaj, Iran \\ E-mail: Safm27@yahoo.com
}

Received: 26-04-2013

Accepted: 28-05-2013

Published: 01-07-2013

doi:10.7575/aiac.ijalel.v.2n.4p.200

URL: http://dx.doi.org/10.7575/aiac.ijalel.v.2n.4p.200

\begin{abstract}
The presence of the Catholic framework in J.R.R. Tolkien's legendarium has long been the subject of debate. Various Tolkien scholars and literary critics have already written different critical interpretations to consider whether to assign The Lord of the Rings and The Silmarillion to Christian Mythology or not; numerous attempts have been made to clarify this statement. Therefore, the reasons, why it should be included in this category are many and various. There are several examples in Tolkien's The Lord of the Rings that can be studied in relation to Christian themes and motives. Consequently, the aims of this paper are to study the possible similarities of Varda, Queen of the Stars, and Galadriel, the Lady of Light, to the Blessed Virgin Mary in Christian contexts. Moreover, to study the influence of Tolkien's strong faith, which shaped his Catholic imagination, all through his legendarium, and subsequently leads us to observe Tolkien's complete obedience to Catholicism, and especially, his profound devotion to the Blessed Virgin Mary.
\end{abstract}

Keywords: Mythology, Christian literature, Catholic imagination, Tolkien's legendarium,

\section{Introduction}

Indeed, Saint John of the Cross narrates and portraits beautifully the "Journey" of the soul or the Journey of initiation, called "The Dark Night", which is defined by the stages of the soul's purification [spiritual cleansing from Sin] throughout the Path of hardships and trials. The aim is the "Purification" of the inner self, which represents the spiritual aspect of Human's Mission on Earth. However, it is only gained through pains and sufferings, imposed on Human's body, soul, and mind:

\section{The Lenten Journey}

\section{Dark night of the soul}

Upon a darkened night

the flame of love was burning in my breast

and by a lantern bright

Ifled my house while all in quiet rest

Shrouded by the night

and by the secret stair I quickly fled

the veil concealed my eyes

while all within, lay quiet as the dead.

$O$, night thou was my guide!

$O$, night more loving than the rising sun!

O, night that joined the Lover to the beloved one!

Transforming each of them into the other

I lost myself to Him

and laid my face upon my Lover's breast

and care and grief grew dim

as in the morning's mist became the light.

There they dimmed amongst the lilies fair. ${ }^{\mathrm{i}}$

Frodo Baggins, the most tragic hero of the Third Age begins his mission, in a world that is about to fall into utter Darkness. The protagonist will experience all kinds of hardships and tests, through his Stygian journey, in order to 
achieve his quest. The main purpose could be seen, as the painful experience that every Man should endure, when he seeks to grow to a spiritual maturity, to finally achieve a union with God.

Turn thou us unto thee, O Lord, and we shall be turned;

Renew our days, as of old. ${ }^{\text {ii }}$

Peace descending

Come ah, come into my breast! ${ }^{\text {iii }}$

"Nothing good or right or virtuous is possible, without Grace. We, as human persons, find our deepest meanings and purposes, fulfilled only when the fire and rose are one." (Eliot, Little Gidding) "For us, the poor, there is no action / but only to wait and to witness." (Eliot, The Rock) Indeed, without Divine's "Grace" nothing but evil and abomination is achieved. According to Saint Thomas of Aquinas, Man cannot be resuscitated from his sins, without the "Help" and "Assistance" of Divine Grace.

Although we have been made aware of the need for this "Absolute Blessing," however, how can we, poor humans, obtain it? In spite of the fact that God's "Door of Grace" is always open and widely available for all Human beings, however, to whom should we turn to, in the first place, to lead us to that Gracious Door...? Should there be a "Mediator" and/or an "Intercessor" for this progress, to show us the way? Fortunately, due to the presence of his mother and Father Morgan, Tolkien found his Spiritual Path, and was blessed by his devotion and strong faith towards this blessed Lady. In fact, it is not an exaggeration to say that Virgin Mary was the most important figure in Tolkien's life.

Although Tolkien's mythical characters, places, and adventures exist in an ancient and pre-Christian era, however, this does not mean that his legendarium is lacking Christian themes. In fact, J.R.R. Tolkien, who is widely regarded as the greatest Catholic author of the post-Christian era ${ }^{\text {iv }}$ had made it clear that, "The Lord of the Rings is of course a fundamentally religious and Catholic work; unconsciously so at first, but consciously in the revision. That is why I have not put in, or have cut out, practically all references to anything like 'religion,' to cults or practices, in the imaginary world. For the religious element is absorbed into the story and symbolism." v

In 1997, George Sayer, Tolkien's close friend offered his opinion and said, "The Lord of the Rings would have been very different, and the writing of it very difficult, if Tolkien hadn't been a Christian." vi Consequently, the significant and memorable characters, such as Gandalf, Galadriel, Aragorn, and Varda [Elbereth], have similar characteristics and resemblance to Jesus Christ and the Virgin Mary, and/or they have some specific manners that remind the reader of those holy figures. All these characters played important roles in the story, by guiding and helping Frodo Baggins.

\section{Varda Elentári [Star-queen], Tolkien's most tender representation of Mary, Queen of Heaven, and Earth}

When one commits sins or does not act, according to his destiny [that which God had willed him to do], or does not act, according to the religious teachings and moral ethics, he has to "repent," in order to be able to return to God's Favor and Grace. Most importantly, one must repent, seek forgiveness, and beseech God's "Pity" and "Mercy," for only then, can he hope to reconcile with his Creator.

As a result, the Mediator and Intercessor should be none other than that "Refugium peccatorum," or the "Refuge of sinners," that "Mater Salvatoris," or the "Mother of the Savior," that "Janua coeli," or the "Gate of Heaven" that "Rosa Mystica," or the "Mystical Rose" that "Regina sacratissimi rosarii," or the "Queen of the most Holy Rosary," who is none other than Mary, Mother of Jesus Christ.

Stratford Caldecott says, "Catholics call Mary Stella Maris, "the Star of the Sea," for reasons that they themselves may find it hard to explain, but the image lies deep within Tolkien's imagination, echoed in the figure of Varda or Elbereth, the Queen of the Stars, venerated by the Elves; and also in Galadriel, who becomes for Frodo, a kind of earthly image of Elbereth, and for Tolkien, a representative of the Virgin Mary." vii

In fact, the Elves' affection and devotion to Varda can be compared to the faithful Catholics' devotion to Mary. In different letters, Tolkien described the Valar as “created spirits, of high angelic order." (Letters, 193) Furthermore, he described them as "regents under God, angelic immortals" [incarnate only at their own will]. (Letters, 193) However, Tolkien was careful to portray them as the guardians, not as the gods to be worshipped, by the people of Middle-earth.

Now, who were, indeed, the Valar? Although, they were not as physical beings at first, however, the Valar could put on visible form, if they wished to, and they appeared fair and noble, akin to Elves, in form, but much greater in majesty, might, wisdom, and splendor. Some of the Valar took forms ${ }^{\text {viii }}$ [as of a male and some as of female; for that difference of temper, they had even from their beginning.] ${ }^{\text {ix }}$ Verlyn Flieger describes the original role of the Valar, "to shape and light the world." $\mathrm{x}$

They were the offspring of Eru's thought and will, and they were his vehicles in shaping Arda, they descended into Eä to assist, in further creation. They are fourteen in number. Those taking male forms are Manwë, Ulmo, Aulë, Oromë, Námo, Irmo, and Tulkas. Those taking female form are called the Valier, and are Varda, Yavanna, Nienna, Estë, Vairë, Vána, and Nessa. Manwë is their sovereign lord, while his queen is Varda, and he only obeys and bows to Eru Ilúvatar. 
In Tolkien's legendarium, Varda and Yavanna have, in fact, more significant roles than the other Valier. Varda [Manwë's queen] was venerated, by the Elves, as Elbereth, Lady of Stars. ${ }^{\text {xii }}$ Together with Manwë, her King and husband, she sent Gandalf, who was one of the five Istari, to aid the free people of Middle-earth against the Dark Lord Sauron. The other Valië is Yavanna, [surnamed Kementári, Queen of the Earth] whose sphere was the world of plants, and who created the Two Trees of Valinor and the ents, to guard plants against the axes of dwarves, [which ironically, are] her husband's creations. ${ }^{\text {xiii }}$

As a Medieval specialist at Oxford University, who had numerous medieval texts and documents at his disposal, and a fervent Catholic, J.R.R. Tolkien was fully aware of Saint Bernard of Clairvaux's sermons and religious interpretations. In one of his invocations, St. Bernard says, "[Mary is] that glorious star which... cast its radiance over the whole world, the star whose splendor rejoices heaven, terrifies hell, and sheds its mild and beneficent influence on the poor exiles of earth...

O you who find yourself tossed about by the storms of life; turn not your eyes from the brightness of this Star, if you would not be overwhelmed by its boisterous waves. If the winds of temptations rise, if you fall among the rocks of tribulations, look up at the Star, call on Mary." (Saint Bernard, Sermons)

In Revelation [12:1], the woman who has "the moon under her feet and upon her head a crown of twelve stars" is by tradition, associated with Mary. Tolkien's Varda is the Star-kindler, the Star Queen, and there are songs or chants about Varda, where the people speak of her stars or praise her, for guiding the wanderers. ${ }^{\text {xiv }}$

Snow-white! Snow-white! O Lady clear!

O Queen beyond the Western Seas!

$O$ Light to us that wander here

Amid the world of woven trees!

Gilthoniel! O Elbereth!

Clear are thy eyes and bright thy breath,

Snow-white! Snow-white! We sing to thee

In a far land beyond the Sea.

O stars that in the Sunless Year

With shining hand by her were sown,

In windy fields now bright and clear

We see your silver blossom blown!

\section{O Elbereth! Gilthoniel!}

We still remember, we who dwell

In this far land beneath the trees,

Thy starlight on the Western Seas. ${ }^{x v}$

Intriguingly enough, Tolkien, in one of his note, on a draft of one of his letters had stated that the Anglo-Saxon star [or star-group] that inspired his Eärendil was often thought to refer to either Christ or Mary. ${ }^{\text {xvi }}$ It is interesting to know that this elven Hymn to Elbereth is in the elven tongue [Sindarin], however, the words and sounds shape themselves in Frodo and Sam's perception into familiar words, which parallels the Marian hymn, "Hail, Queen of Heaven", written by Father John Lingard. ${ }^{\text {xvi }}$

Hail, Queen of Heaven, the ocean star,

Guide of the wanderer here below,

Thrown on life's surge, we claim thy care,

Save us from peril and from woe.

Mother of Christ, Star of the sea

Pray for the wanderer, pray for me. 
O gentle, chaste, and spotless Maid,

We sinners make our prayers through thee;

Remind thy Son that He has paid

The price of our iniquity

Virgin most pure, Star of the sea,

Pray for the sinner, pray for me.

It is fair to assume that both Frodo and Sam, somehow unconsciously or unwillingly, invoke the name of Elbereth various times. Frodo invokes her when the Ringwraiths attack at Weathertop, or in another instance, when they pursued him to the ford outside Rivendell. Moreover, it is worth pointing out that Aragorn explained that the name of Elbereth was far dangerous and more deadly to the Ringwraiths, than the sword.

Furthermore, when Sam wounded Shelob, by a deep gash upon her body, he put off the Phial of Galadriel, and he too called on Elbereth, "then his tongue was loosed and his voice cried in a language, which he did not know..." (Tolkien, The Two Towers)

\section{A Elbereth Gilthoniel o menel palan-diriel, le nallon \\ si di-nguruthos! A tiro nin, Fanuilos!}

According to Tolkien's own translation, it means, "O Queen, who kindled star on star, white-robed from heaven gazing far, here overwhelmed in dread of Death I cry: O guard me, Elbereth!"

In another of his letters, Tolkien offers another translation, which is more literal, "O Elbereth Starkindler from heaven gazing-afar, to thee I cry now, in the shadow of (the fear of) death. O look towards me, Everwhite." xviii

That is why Sam's prayer gives him enough might and strength to confront and attack the evil spawn of Ungoliant. However, Tolkien, himself commented that neither Frodo nor Sam deliberately and consciously called for the intercession of the higher powers. As a result, "Grace" was bestowed upon Frodo and Sam, so that they may be able to call on "Grace". Indeed, the servants of Ilúvatar helped and assisted other servants of Ilúvatar. (Birzer, Sanctifying Myth)

On the other hand, the wife of Manwë, who is the maker of light and stars is known as the "Queen of Heaven" and the "Star of the Sea, and is the counterpart of Virgin Mary in Catholic Theology. The Elves invoke her and seek fervently her "Intercession" and "Grace" in their prayers, more than any other Valar. ${ }^{\text {xix }}$ Therefore, it is reasonable to consider that Tolkien's angelic Elbereth stands as a Marian figure in his legendarium.

Another interesting example concerning Varda can be seen in the Dagor Dagorath [Sindarin, Battle of all Battles], also known, as the Second Prophecy of Mandos. It is Tolkien's mythological equivalent of the Norse "Ragnorak", and St. John's "Apocalypse". It is the final titanic Battle of the two opposing forces, along with their followers, which will be followed, by the final victory of Ilúvatar and his allies over Morgoth the Evil. ${ }^{\mathrm{xx}}$ In Catholicism, the image of the woman "clothed with the sun", who is ready to give a second birth to the Messiah is none other than the Virgin Mary. "A great and wondrous sign appeared in Heaven: a woman clothed with the sun, with the moon under her feet, and crown of twelve stars on her head." $\times x i$

As a result, in the Silmarillion, Varda set the Constellation, Menelmacar, [an Elvish Quenya name, for the Swordsman of the Sky or swordsman of the heavens, which, most likely stands for the constellation of Orion], to notify the awakening of the Elves, moreover, to prophecy the final Battle against the Dark and Evil Army ${ }^{\mathrm{xxii}}$. Furthermore, it has been told that the Constellation of Menelmacar signifies Túrin Turambar, son of Húrin, whose spirit will rise again from the halls of Mandos; "and with his black sword [Gurthang], he shall deal unto Morgoth his death and [his] final end; and so shall the children of Húrin and all Men be avenged." xxiii

\section{The curious case of Galadriel, The Lady of the Golden Wood}

From the very beginning of The Lord of the Rings, until the very last, Christian themes can be traced in almost every chapter; these themes exist as a significant aspect of each person. That is why Galadriel, the Lady of Lórien, who is among Tolkien's strongest and most vividly drawn characters is probably one of the most powerful and inspiring representations of the Blessed Mary. It is perhaps fair to assume that Galadriel was one of Tolkien's most favorite figures in his legendarium. He described her as "the mightiest and fairest of all the Elves that remained in Middle-earth" (Tolkien, The Silmarillion) and the "greatest of elven women" (Tolkien, The Lord of the Rings)

However, some Christians consider almost impossible to prove such comparison, and some Tolkien scholars as well may question the veracity of such similarities and likeness; especially by referring to some of Galadriel's manners, such as her pride, or her rebellion against the Valar [the Angelic guardians] and her childbearing. However, some of Galadriel's key aspects make this analogy almost possible, and worthy of deeper reflections. 
Pride and arrogance, [which are Noldor's prime particularities in their temperaments] have never been the characteristics of the Virgin Mary. Great religious figures, such as Bernard of Clairvaux and Thomas of Aquinas have mentioned Mary's utmost humility before the Divine Will as her paramount virtue. Various artists, who portrayed the Annunciation have employed a standard iconographic pose of a demure young woman with head bowed and hands folded. ${ }^{\text {xxiv }}$ In contrast, someone like Michael W. Maher goes on to say emphatically, "Galadriel, this warrior-woman rebelling against the Valar bears greater resemblance to Lucifer, the angel of light, who chose to rule in Hell, rather than to serve in Heaven. "xxv

In like manner, "Galadriel brought to life a daughter, named Celebrian, without miraculous intervention [in contrast to the Blessed Virgin]; therefore, there is no parallel with Mary's virginity. By considering these facts, it is indeed impossible such a theory." (Maher, A land without stain)

However, Burns called attention to the complex and unique case of Galadriel "As she developed in the drafts of Tolkien's legendarium, in contradistinction to the gelled version, from the published Silmarillion, and invited readers to ponder just how Marian, a rebel is, and consider that "hints of the lesser-than-ideal" do in fact, hover around Galadriel's character." (Burns, Perilous Realms)

Lesley Marx placed Galadriel, along with Gandalf, Aragorn, and Frodo as the figures, who can be considered as the identity of Christ. ${ }^{\text {xxvi }}$ Some other critics believe that it is Aragorn instead, who resembles to the Blessed Mary, in the manner of his death; he dies of his own decision and free will, which is similar to Virgin Mary in Catholicism. Moreover, we see Tolkien, stating in 1958, "[A man] would or should die voluntarily, by surrender with trust before being compelled." (Carpenter, The Letters of J.R.R. Tolkien) Indeed, Man should accept his gift of freedom; it is Man's destiny to leave the world. Thus, Man's acceptance would be nothing but a glorification of God Almighty and an utmost trust to his Creator.

In addition, Donald Richmond spoke of a Marian influence, “...through the socio-psycho-pneumatically linked "homes" of mother-love [Mabel], Mother Church, the Blessed Mother and Edith-[Tolkien's] Lúthien, and the mother of their children. These, constitute the feminine "compass", guiding the Rings, in its writing as well as (through certain feminine characters within his texts) the entire landscape of Middle-earth." xxvii

Thereupon, in regard to Galadriel's image, some other opinions have suggested that the figure of Galadriel, in Lothlórien can be seen as the symbolic figure of the Church in its feminine aspect; that is, as "the bride of Christ", which Catholics refer to it as "our Mother the Church". In fact, the same thing can be seen in Dante's Paradise, when the Italian poet presents Beatrice, as the symbolic figure of the Church.

Indeed, Cath Filmer-Davies says, "Galadriel signifies the Church, not the Virgin Mary, because Galadriel is not a virgin. Although Galadriel is not beyond the temptation to power, offered by the Ring, however she rejects it and does not succumb to temptation; as a result, Galadriel could be considered as a holy figure." xxviii

There are, additionally, images of the functions of the Church, and the Provision for Sacramental Grace, in some parts of the story. The spiritual food of bread and wine could then be seen in the Provision of the "miruvor", the healing cordial of Imladris, and the "lembas", the Elven way-bread, which strengthens and sustains the members of the fellowship [who could be considered as pilgrims] in times of hardship. ${ }^{\text {xxix }}$

When Frodo and his fellowship entered to Lothlórien, they met Haldir, [probably a Silvan Elf...] of Lorien, who told them, "You feel the power of the Lady [not the Lord] of the Galadrim", "xx (Tolkien, The Fellowship of the Ring) and Lórien is Galadriel's dwelling place, called the "Golden Land". Galadriel's pure, radiant, and most graceful appearance, both in physical and spiritual forms reflected in her land, which she nourished and sustained with her magical Ring: Nenya. Incidentally, this same attribute can be found in "Loretto's Litany", where the Blessed Virgin has been called "Domus Aurea" xxxi or the "House of Gold". xxxii

Another instance is the attribute of "Immaculata" or "She, who is without stain", which, throughout human History belongs only to Mother Mary. Once again, this does not exactly apply to Galadriel, but to her land; in fact, Lórien has certainly been called as a pure land, without stain, "No blemish or sickness could be seen in anything that grew upon the earth. On the land of Lórien, there was no stain..." (Tolkien, The Fellowship of the Ring)

Another particular title, given to the Blessed Virgin, in the "Loretto's Litany" is "Stella Matutina" or the "Morning Star", which could be connected to Galadriel, as the "Giver of the Light of Eärendil's star", which is the last surviving Silmaril, as a light, when all other lights go out... It sustained and helped Frodo and Sam on their Journey in Mordor. (Flieger, Splintered Light)

Another example is Galadriel's pity and mercy, which was shown in her confrontation with Gimli, the dwarf. This shows that Galadriel has something that her husband, Celeborn lacks. Indeed, it is Galadriel, who corrects Celeborn's inappropriate manner and hostile words towards Gimli. (Tolkien, The Fellowship of the Ring) In fact, one may see that Galadriel stands as an example of Mercy and Pity, "Forgiveness, hospitality, understanding," and she "Serves as a model for toleration of difference." xxxiii

Therefore, these interesting instances make this analogy almost acceptable, and worthy of deeper reflections. Moreover, in the late 1971, Tolkien himself spoke about this matter and declared, "I think it is true that I owe much of this character to Christian and Catholic teaching and imagination about Mary, but actually Galadriel was a penitent: in her youth, a leader in the rebellion against the Valar (the angelic guardians). At the end of the First Age, she proudly refused forgiveness or permission to return. She was pardoned because of her resistance to the final and overwhelming 
temptation to take the Ring for herself." (Letters, 407) According to Tolkien's biographer Humphrey Carpenter, Tolkien asserted that, "I dislike allegory wherever I smell it" (Letters, 193) or "I dislike Allegory - the conscious and intentional allegory..." xxxiv (Letters, 131)

In her turn, Marjorie Burns says, "It is Galadriel, not Varda, who is positioned to meet the members of the Fellowship, face to face, and read their heart and mind." Furthermore, it is Galadriel, who gives Frodo "a small crystal phial," in which the light of Eärendil's star ${ }^{\mathrm{xxx}}$ [a star placed in the heavens, by Varda], glimmers amid waters from her fountain; and there, she prays, "Be a light to you in dark places, when all other lights go out." xxxvi

She then says, "Through Galadriel, then, a tangible contribution from Varda is made available to the quest. When Sam touches the phial after wounding of Shelob, he first calls out Galadriel's name and then calls on Elbereth. [This image is] more than a little suggestive of Catholic invocations to Mary, the Saint on high.xxxvii

To assert this idea, some other scholars believe that the phial may associate with the Christian ritual of baptism; furthermore, such interpretations connect the phial to Christ's words, in the "Revelations," "He, who conquers and who keeps my works until the end... I will give him the morning Star." xxxviii (Revelation 2:26-29) In like manner, the Elven way-bread, lembas, which sustains the members of the Fellowship [the pilgrims] in their hardships and trials, ${ }^{\text {xxix }}$ could be identified with the Eucharist, in Catholic rituals.

\section{Twenty-fifth of March, the "Annunciation" of the Blessed Virgin Mary}

"Behold! The Angels said, "O, Mary! Allah has chosen you, and purified you, chosen you above the women of all nations! O, Mary! Worship your Lord devoutly: prostrate yourself, and bow down (in prayer) with those who bow down." This is part of the Tidings of the things unseen, which We reveal unto you (O Messenger!) by inspiration." xl

Indeed, this date is one of the most important spiritual days in the Christian Canonical Calendar. It is the glorification of the "Annunciation"; Christians celebrate the Incarnation of Christ, the "World" becoming "Flesh", in the womb of the Blessed Virgin. It is also traditionally believed to be the date of Christ's Crucifixion. Moreover, Annunciation Day was the start of the New Year in most European countries during the Middle-Ages as well. ${ }^{\mathrm{xli}}$

In one of the appendices to The Lord of the Rings, Tolkien mentioned that "March 25th is the date of the downfall of the Barad-dûr, [or the Dark Tower]", moreover, he states that, "In commemoration of the fall of Sauron and the deeds of the Ring-bearers, the New Year began on March 25." xlii

Indeed, the day of the destruction of the Ring, in Tolkien's mythos is worthy of deep attention. Tom Shippey says, "In Anglo-Saxon belief, and in European popular tradition, both before and after that, 25 March is the date of the Crucifixion and that of the Annunciation (that is, nine months before Christmas); it is also the last day of Creation. By mentioning this special date, Tolkien was presenting his "eucatastrophe" as a forerunner or "type" of the greater one of Christian myth." Moreover, Shippey believes that Tolkien leads his readers "to the edge of Christian reference", "at which Revelation seems very close, and allegory does all but break through naturally enough, a moment of eucatastrophe to use Tolkien's term for sudden moments of fairy-tale salvation." xliii

\section{The existence of the "Holy Spirit"}

Unlike Galadriel, whose similarities with the Virgin Mary are covered with a veil of uncertainty, the existence of "the One" [the Almighty,] in Tolkien's legendarium is clear as crystal. In fact, Tolkien harmoniously combined several philosophical and theological aspects, such as Judeo-Christian Theology, Stoic, and Platonic Philosophy, and almost some of Northern Germanic and Scandinavian Mythology, to create his perception of God Almighty. Therefore, it could be said that Eru [Quenya means All-Father - Heavenly Father] is Tolkien's equivalent of the First Person of the Christian Trinity, who is God the Father. ${ }^{\text {xliv }}$ Indeed, in an interview in 1968, Tolkien had firmly asserted, "The book is about the world that God created - the actual world of this planet."

In his book, "Tolkien and The Silmarillion", Clyde S. Kilby says, "Professor Tolkien talked to me at some length about the use of the word "Holy" in The Silmarillion. Very specifically, he told me that the "Secret Fire sent to burn at the heart of the World" in the beginning was the Holy Spirit." "Therefore Ilúvatar gave to their vision Being, and set it amid the Void, and the Secret Fire was sent to burn at the heart of the World; and it was called Eä." (Tolkien, The Silmarillion)

The Flame Imperishable or the Secret Fire is a mysterious, powerful life force, which has the ability to create [lifegiving], that only Eru [Ilúvatar] possesses. ${ }^{\text {xlv }}$ Melkor is the perfect example of the sin of possessiveness, by considering his hunger for power and his desperate efforts to seize the mysterious force of the Flame Imperishable; moreover, he later steals the Fëanor's Silmarils for his dark crown.

It is important to notice that even the Dwarves [or Khazâd, ${ }^{\text {xlvi }}$ Aulë's creation] had not the gift of freedom and an independent life of their own will; they could only live and act when Aulë's thought and will were upon them. (Tolkien, The Silmarillion) As a result, Ilúvatar considered Aulë's unauthorized and thoughtless creation of the Dwarves as an offense, and questioned his intention and inner thoughts. ${ }^{\text {xlvii }}$ Therefore, Aulë, who had exceeded his power, repented and expressed his utmost submission towards Eru. He later assumed that he should destroy his own creations [the seven Fathers of the Dwarves] with his great hammer. However, Ilúvatar, who perceived Aulë's humility and submission towards himself stopped him, and expressed his wish in accepting the Dwarves as his adopted children, and then gifted them with spirits and will of their own. 
Verlyn Flieger believes that, "Aulë's unquestioning acceptance of Eru's chastisement his willingness to destroy his creatures recalls the unquestioning obedience of biblical Abraham and his willingness to sacrifice his son Isaac at his God's Command. "xlviii

The reader should then pay attention to the fact that several times, throughout Ainulindalë, Tolkien intentionally capitalized the term "Being" alongside Iluvatar's use of "the Flame Imperishable," to put an emphasis in the act of Creation [to create things that are ontologically independent from Ilúvatar ${ }^{\text {xlix }}$ ]. Therefore, it is fair to consider "the Flame Imperishable" or "the Secret Fire," as Tolkien's mythological representation of the Third Person of the Trinity. ${ }^{1}$

It is worth pointing out that when Gandalf encountered a Balrog [Durin's Bane] at the Bridge of Khazad-dûm, he firmly stood in front of that Balrog and announced, "You cannot pass", he continued, "I am a servant of the Secret Fire, wielder of the flame of Anor. You cannot pass. The dark fire will not avail you, flame of Udûn. Go back to the Shadow! You cannot pass."li Thus, it is perceived that Gandalf is the servant of Ilúvatar, the possessor of the Flame Imperishable.

\section{Conclusion}

Various scholars believe that in his legendarium, Tolkien delicately portrayed the image of the wayfaring "Christian Quest," on a Mystical Journey to Redemption. At both, Rivendell and Lothlórien, counsels are offered, and as a result, the power of moral and spiritual strength is renewed. At Rivendell, Frodo accepts the Call on his life, to be the Ringbearer, though he admits frankly, "I do not know the Way..." Interestingly, the Way being the biblical name for Christianity.

In spite of some skepticism, concerning similarities to Christian themes and motives, in 1978 James Lynch proposed another strong idea; he considered the feast scenes of The Lord of the Rings as some types of Eucharistic feast.

He identified Bilbo's farewell party with the feast in Lothlórien, hosted by Lady Galadriel, as an identification of the "Last Supper" of Jesus Christ. Each one is focused on a departure [which could be interpreted as an Initiation] and greater errand. ${ }^{\text {lii }}$ Accordingly, Stratford Caldecott believes that Gandalf, Aragorn, and Frodo, could be seen as "Christian heroes" and some kind of "Christ-figure." "liii Jean Chausse in his turn suggests that the three specific figures of Christ or "facets of the personality of Jesus," as the Laborer, Sufferer, and the King correspond respectively to Gandalf, Frodo, and Aragorn. ${ }^{\text {liv }}$

One should add, here, that Tolkien's mother, along with Father Francis Morgan, [his spiritual and legal guardian after his mother's death] had profound effects on Tolkien's faith and religious thoughts. Tolkien himself said, "I first learned charity and forgiveness from him." lv

Indeed, in response to a letter, sent by Father Robert Murray, Tolkien voiced his opinion and said, "I know exactly what you mean, by the order of Grace; and of course, by your references to Our Lady, upon which, all my own small perception of beauty, both in majesty and simplicity is founded. The Lord of the Rings is, of course, a fundamentally religious and Catholic work; unconsciously so at first, but consciously in the revision. I have cut practically all references to anything like "Religion", to cults and practices in the imaginary world. For the religious element is absorbed into the story and symbolism. However, that is very clumsily put, and sounds more self-important than I feel. For, as a matter of fact, I have consciously planned very little; and should chiefly be grateful for having been brought up (since I was eight) in a Faith that has nourished me, and taught me all the little that I know..." lvi

Although Tolkien disliked formal or crude allegory, it is reasonable to believe that in some parts of the story, Frodo Baggins stands as a Christ figure; he has the image of the one, who bears the Cross, to unmade the Original Sin, and bring hope and redemption for all the people. According to Christian belief, Christ unmade the Original Sin with his life, death, and resurrection. As a result, if the One Ring is simultaneously equivalent with the concept of Sin in general, and Original Sin in particular, thus, the Christocentric aspects of this story will be fully manifested. ${ }^{\text {lvii }}$ Therefore, as long as the One Ring is considered as the Original Sin, the argument sounds then, most plausible!

Furthermore, there are also other characters that could be seen as Christ figures, such as Gandalf with his "resurrection," and "transfiguration," which are similar to Christ's Mystical and Spiritual Transfiguration. Moreover, Aragorn's descent to the Paths of the Dead is similar to Christ's descent into Hell, following his Crucifixion. Aragorn is the "King of the Dead," just as Christ, who has the power to set the suffering souls, free of their torments, is seen as such. Furthermore, as a healer, Aragorn bears another interesting resemblance to Christ. ${ }^{\text {lviii }}$

In 2005, Boyle mentioned that, to miss the Catholic outlook of The Lord of the Rings is to miss the whole plot, "The success of Frodo's Mission is a Salvation, which only a Catholic view of life can explain. To interpret the "Quest" and its end, without reference to Tolkien's Catholicism is to lose a whole dimension of its significance." lix

Indeed, Tolkien strongly believed that Myth is deeply rooted in Christian Theology. Thus, by highlighting the role of God's Grace, throughout his legendarium, he showed that the necessity of having the essence of heroism comes from God's Pity, Mercy, and, Grace, and not from sword and sorcery or Human's will. It can be concluded that, J.R.R. Tolkien intended to design his Myth as Christian as possible, however, he tried his best to avoid any explicit references to Christian Theology. In "The Monsters and the Critics", Tolkien clarified his fear of it, and explained that if the author makes his meaning too explicit, therefore he risks destroying the art, a deeper significance, and the internal layers of his work. C.S Lewis confirms that and says, "The essence of a Myth [is] that it should have no taint of allegory to the maker and yet, should suggest incipient allegories to the reader." ${ }^{1 \mathrm{x}}$ 
As a result, the researcher tried to show the pros and cons of such opinions, studied by various scholars, about any possible connection with Christian themes. Obviously, this is still an ongoing debate between authorial intentionality and readerly applicability, in Christian references in The Lord of the Rings.

Therefore, a Christian reader could find several examples that could be allegories, not in the sense of portraying political events of Tolkien's era, but in the sense of Christian Parable. Thus, one cannot deny the fact that if a devout and faithful author intends to write about "Pity" and "Mercy" or uses these divinely terms as the basis of his framework, he would certainly remember: "Virgin Clemens" or the "Virgin most Merciful" that could be highlighted in his story, whether consciously or unconsciously.

Thus, from Tolkien's perspective, God offered Mary's image to the world, along with her life story, "To refine so much our gross manly natures and emotions, and also of warming and coloring our hard, bitter, religion."

The idea and purpose that she is indeed serving as the human Tabernacle for the Second Covenant, the Christ, means that she must be impeccably and awesomely beautiful, Tolkien argued. Therefore, every beautiful aspect that Tolkien created came from his own limited notions and understanding of Mary, as he had claimed. In an unpublished letter to Clyde Kilby, Tolkien wrote, "There is something missing from any form of "Christian Thought" that could make such an omission. A failure (I think), to accept fully, all the consequences of the Incarnation story, as it is told to us in Scripture." Thus, in a very personal effort, Tolkien reflected upon the decisions of some of the earliest Ecumenical Church Councils, where churchmen had proclaimed dogmas about Mary, which pointed out that they should not elevate Mary, but elevate Christ.

Tolkien strongly believed that Humans, or for that matter, all Human being, [or all Adam's progeny...] should turn to the Blessed Mary, who has always been called "La Misericordiosa" [or She, who grants Mercy], for she has always been represented as the "Manifestation" of Divine "Pity" and "Mercy."

Therefore, Tolkien's readers can find many and various Christian themes, all through his legendarium, which lead mostly to only one conclusion: Tolkien's complete obedience to Catholicism, and especially, his profound devotion for the Blessed Virgin Mary, who is the universal symbol of Mercy and Compassion. Perhaps it is fair to believe that The Lord of the Rings is not a pure Christian allegory, in an explicit manner, however, Tolkien's legacy is a Quest, clothed in Myth, as a way of glorifying God Almighty.

\section{References}

Birzer, B. (2003). J. R. R. Tolkien's Sanctifying Myth: Understanding Middle-earth. Wilmington: Isi Books.

Birzer, B. (2001). The Christian Gifts of J.R.R. Tolkien, New Oxford Review 68, no. 10 , 25-29.

Bloom, H. (Ed.). (2000). J. R. R. Tolkien's Lord of the Rings (Modern Critical Interpretations). Philadelphia: Chelsea House Publications.

Boyd, I., \& Stratford, C. (2003). A Hidden Presence: The Catholic Imagination of J.R.R. Tolkien. New Jersey: Chesterton Press.

Burns, M. J. (2005). Perilous Realms: Celtic and Norse in Tolkien's Middle-earth. Toronto: University of Toronto Press.

Caldecott, S. (2005). The Power of the Ring: The Spiritual Vision Behind "The Lord of the Rings". New York: Crossroad Publishing Company.

Caldecott, S. ( 2003). Secret Fire: The Spiritual Vision of J.R.R. Tolkien. London: Darton, Longman, and Todd.

Carpenter, H. (1977). The Authorized Biography of J.R.R. Tolkien. London: Allen \& Unwin.

Carpenter, H. (1979). The Inklings: C. S. Lewis, J.R.R. Tolkien, Charles Williams, and Their Friends. Boston: Houghton Mifflin.

Carpenter, H. (1981). The Letters of J.R.R. Tolkien. London: Allen \& Unwin.

Chance, J. (2001). Tolkien's Art: A Mythology for England. Lexington: University Press of Kentucky.

Chance, J. (Ed.). (2003). Tolkien the Medievalist. London; New York: Routledge.

Drout, M. D. C. (Ed.). (2006). J. R. R. Tolkien Encyclopedia: Scholarship and Critical Assessment. New York City: Routledge.

Eliot, T. S. (1967). The Complete Poems and Plays. New York: Harcourt Brace.

Flieger, V. (2002). Splintered Light: Logos and Language in Tolkien's World. Kent, OH: Kent State University Press.

Flieger, V. (1999). Fantasy and Reality: J. R. R. Tolkien's World and the Fairy Story Essay. Mythlore: A Journal of J. R. R. Tolkien, C. S. Lewis, Charles Williams, and Mythopoeic Literature. 22, no. 3.

Kerry, P. E. (2011). The Ring and the Cross Christianity and the Writings of J.R.R. Tolkien. UK: Fairleigh Dickinson University Press.

Kocher P. H. (1985). Ilúvatar and the Secret Fire. Mythlore: A Journal of J. R. R. Tolkien, C. S. Lewis, Charles Williams, and Mythopoeic Literature. 12.1, 36-37.

Kocher, P. H. (1972). Master of Middle-earth: The Achievement of J.R.R. Tolkien. London: Thames \& Hudson. 
Montgomery, J.W. (1974). Myth, Allegory, and Gospel: An Interpretation of JRR Tolkien, CS Lewis, GK Chesterton, Chas Williams. Bloomington, Minnesota: Bethany House.

Plath, S. (2000). The unabridged journals. K. V. Kukil (Ed.). New York: Anchor.

Shippey, T. (2001). J.R.R. Tolkien: Author of the Century. Boston: Houghton Mifflin.

Shippey, T. (1992). The Road to Middle-earth. London: Grafton.

Tolkien, J.R.R. (2004). The Lord of the Rings. Boston: Houghton Mifflin.

Tolkien, J.R.R. (1965). The Hobbit. New York: Ballantine Books.

Tolkien, J.R.R. (1977). The Silmarillion. Christopher Tolkien (Ed.). Boston: Houghton Mifflin.

Tolkien, J.R.R. (2007). The Children of Húrin. Christopher Tolkien (Ed.). Boston and New York: Houghton Mifflin.

Tolkien, J.R.R. (1987). The Lost Road and Other Writings. Christopher Tolkien (Ed.). London: Allen \& Unwin.

Tolkien, J.R.R. (1996). The Book of Lost Tales. Two Parts. The History of Middle-earth 1-2. Christopher Tolkien (Ed.). London: Allen \& Unwin.

Tolkien, J.R.R. (1996). The Lays of Beleriand. Christopher Tolkien (Ed.). London: Allen \& Unwin.

Tolkien, J.R.R. (1986). The Shaping of Middle-earth. Christopher Tolkien (Ed.). London: Allen \& Unwin.

Tolkien, J.R.R. (2002). The Return of the Shadow. Christopher Tolkien (Ed.). London: Harper Collins.

Tolkien, J.R.R. (2001). The Treason of Isengard. Christopher Tolkien (Ed.). London: Harper Collins.

Tolkien, J.R.R. (1990). The War of the Ring. Christopher Tolkien (Ed.). Boston: Houghton Mifflin Company.

Tolkien, J.R.R. (2002). Sauron Defeated. Christopher Tolkien (Ed.). London: Harper Collins.

\section{Notes}

\footnotetext{
${ }^{\mathrm{i}}$ Saint John of the Cross Loreena McKennitt, 1993. Underhill, Evelyn. (Re-issue 1999). Mysticism, Oneworld Publications. ISBN 1-85168-196-5.

${ }^{i i}$ Coulombe, Catholic View, 65.

iii Selected Poems" in Goethe and Religion. Special Issue of Literature and Belief 20, no. 2 (2000): 163.

iv Ken Craven, "Catholic Poem" 163.

${ }^{\mathrm{v}}$ Tolkien to Father Robert Murray, December 2, 1953, Letter142.

${ }^{v i}$ Pearce, Joseph, Tolkien: Man and Myth. San Francisco. 1998.100.

vii Caldecott, Stratford, Over the Chasm of Fire: Christian Heroism in The Silmarillion and The Lord of the Rings." In Pearce, Tolkien: A Celebration. 12.
}

Kerry, Paul E, ed. The Ring and the Cross Christianity and the Writings of J.R.R. Tolkien, UK: Fairleigh Dickinson University Press, 2011.

The Power of the Ring: The Spiritual Vision Behind "The Lord of the Rings." Revised and expanded edition of Secret Fire: The Spiritual Vision of J.R.R. Tolkien. New York: Crossroad Publishing Company, 2005.

viii Dickerson, Matthew, "Valar". J.R.R. Tolkien Encyclopedia: Scholarship and Critical Assessment, Ed. Michael D.C. Drout. New York/London: Routledge, 2007. 725

${ }^{i x}$ Tolkien, J.R.R. The Silmarillion. Edited by Christopher Tolkien. New York: Ballantine Books; Boston: Houghton Mifflin, 1977. 21.

${ }^{\mathrm{x}}$ Flieger, Verlyn. Splintered Light. Logos and Language in Tolkien's World. Kent, OH: Kent State University Press, 2002. 58 .

${ }^{x i}$ Dickerson, Matthew, "Valar". J.R.R. Tolkien Encyclopedia: Scholarship and Critical Assessment, Ed. Michael D.C. Drout. New York/London: Routledge, 2007. 725

xii Crowe, Edith L. "Power in Arda: Sources, Uses, and Misuses." In Proceedings of the J.R.R. Tolkien Centenary Conference, Ed. Patricia Reynolds and Glen Good- Knight. Milton Keynes and Altadena, CA: The Tolkien Society and the Mythopoeic Society, 1995. 272-77.

xiii Carol A. Leibige, "Women in Tolkien's Works". J.R.R. Tolkien Encyclopedia: Scholarship and Critical Assessment, Ed. Michael D.C. Drout. New York/London: Routledge, 2007, 747.

Tolkien, J.R.R. The Silmarillion. Edited by Christopher Tolkien. New York: Ballantine Books; Boston: Houghton Mifflin, 1977. 46. 
${ }^{\mathrm{xiv}}$ Kerry, Paul E, ed. The Ring and the Cross Christianity and the Writings of J.R.R. Tolkien, UK: Fairleigh Dickinson University Press, 2011. 250.

${ }^{\mathrm{xv}}$ Tolkien, Fellowship of the Ring (1987), 88-89.

xvi Tolkien to "Mr. Rang," drafts, undated [August 1967], in Tolkien, Letters, 385. Kerry, Paul E, ed. The Ring and the Cross Christianity and the Writings of J.R.R. Tolkien, UK: Fairleigh Dickinson University Press, 2011.

${ }^{x v i i}$ Venerable Father John Lingard (1771-1851), was a Catholic Priest and historian who, through the precious works of William Cobbett, assisted in preparing the appropriate passage of the Catholic Emancipation Act in England. His tender Marian hymn, was based on the medieval Latin plainchant Ave Maris Stella.

In fact, Stratford Caldecott was the first scholar, who noticed and recognized similarities between Tolkien's description of Varda with the "Hail, Queen of Heaven" in Secret Fire: The Spiritual Vision of J.R.R. Tolkien.

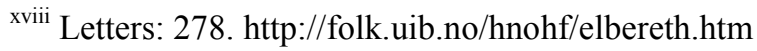

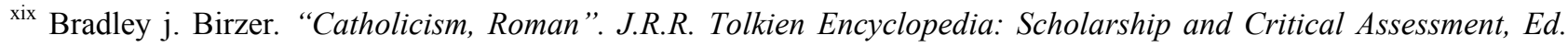
Michael D.C. Drout. New York/London: Routledge, 2007, 125.

${ }^{\mathrm{xx}}$ Tolkien, J.R.R. The Shaping of Middle-earth. Edited by Christopher Tolkien. London: Allen \& Unwin, 1986.

The Lost Road and Other Writings. Edited by Christopher Tolkien. London: Allen \& Unwin, 1987.

${ }^{x x i}$ In the twelfth chapter of the Apocalypse

xxii Tolkien, J.R.R. The Silmarillion. Edited by Christopher Tolkien. New York: Ballantine Books; Boston: Houghton Mifflin, 1977. "Quenta Silmarillion: Of the Coming of the Elves and the Captivity of Melkor".

Tolkien, J.R.R. Morgoth's Ring: The Later Silmarillion. The History of Middle-earth 10. Edited by Christopher Tolkien. Boston and New York: Houghton Mifflin Company, 1993.

xxiii Tolkien, J.R.R. The Lost Road and Other Writings. Edited by Christopher Tolkien. London: Allen \& Unwin, 1987. "The conclusion of the Quenta Silmarillion". 333

Pearce. Joseph. “Darkness”. J.R.R. Tolkien Encyclopedia: Scholarship and Critical Assessment, Ed. Michael D.C. Drout. New York/London: Routledge, 2007, 154

Burns, Marjorie. Perilous Realms: Celtic and Norse in Tolkien's Middle-earth. Toronto: University of Toronto Press, 2005. Pearce, Joseph. Tolkien: Man and Myth. London: Harper- Collins, 1998.

${ }^{\text {xxiv }}$ Michael W. Maher, S.J. "A land without stain” Medieval images of Mary and their use in the characterization of Galadriel. One of the favorite subjects for the artists of the late Middle Ages and Renaissance was the concept of Annunciation. To portray and show the Virgin Mary's submission to the will of God, with her hands folded across her breast and head bowed.

${ }^{\mathrm{xxv}}$ Michael W. Maher, S.J. “A land without stain” Medieval images of Mary and their use in the characterization of Galadriel.

xxvi 1992, Marx, "Mirror of Galadriel," 45.

xxvii 2002, Richmond, “Tolkien's Marian Vision,” 13.

xxviii Cath Filmer-Davies. "Theology in The Lord of the Rings". J.R.R. Tolkien Encyclopedia: Scholarship and Critical Assessment, Ed. Michael D.C. Drout. New York/London: Routledge, 2007,681. Carson, H.M. "Roman Catholicism.' In The New International Dictionary of the Christian Church, edited by J.D. Douglas et al., 853-56. Grand Rapids, MI: Zondervan 1978.

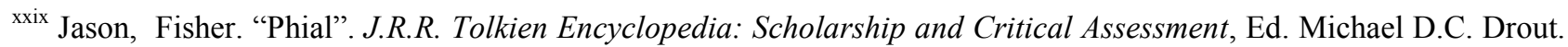
New York/London: Routledge, 2007, 544.

Carson, H.M. "Roman Catholicism.' In The New International Dictionary of the Christian Church, edited by J.D. Douglas et al., 853-56. Grand Rapids, MI: Zondervan 1978.

Humphrey Carpenter, J.R.R. Tolkien: A Biography. London: Allen \& Unwin, 1977.

Cath Filmer-Davies. "Theology in The Lord of the Rings". J.R.R. Tolkien Encyclopedia: Scholarship and Critical Assessment, Ed. Michael D.C. Drout. New York/London: Routledge, 2007,681-682.

${ }^{\mathrm{xxx}}$ Tolkien, J.R.R. The Lord of the Rings. Fiftieth anniversary edition. Boston: Houghton Mifflin, 2004. FR, II, vi, 342.

${ }^{x x x i}$ One of the most popular Litanies in the Sixteenth Century was the litany of Loretto. This city in Italy holds a rare honor of being the fortunate host of the genuine house of the Blessed Mary, located in Nazareth, in Palestine, where she received the Annunciation from the Archangel Gabriel. (Michael W. Maher, S.J. A Land without stain)

xxxii “The Mistress of Magic, who dwells in the Golden Wood" TT, 348. Michael W. Maher, S.J. A Land without stain, Medieval images in the characterization of Galadriel.

xxxiii Chance 54, Nancy Enright. Tolkien's Females and the Defining of Power.

${ }^{\text {xxxiv }}$ Letters, 131 
${ }^{x x x v}$ This same light appears in her ring Nenya

${ }^{x x x v i}$ Burns, Marjorie "Saintly and distant mothers". Kerry, Paul E, ed. The Ring and the Cross Christianity and the Writings of J.R.R. Tolkien, UK: Fairleigh Dickinson University Press, 2011. 252.

Fisher, Jason. "Phial". J.R.R. Tolkien Encyclopedia: Scholarship and Critical Assessment, Ed. Michael D.C. Drout. New York/London: Routledge, 2007,P 543-544

Tolkien, J.R.R. The Lord of the Rings. Boston and New York: Houghton Mifflin, 1994. 393.

${ }^{x x x v i i}$ Burns, Marjorie "Saintly and distant mothers". Kerry, Paul E, ed. The Ring and the Cross Christianity and the Writings of J.R.R. Tolkien, UK: Fairleigh Dickinson University Press, 2011. 252.

Tolkien, J.R.R. The Lord of the Rings. Boston and New York: Houghton Mifflin, 1994. Two Towers (1987), 329-31

xxxviii Revelation 2:26-29

${ }^{\text {xxxix }}$ Cath Filmer-Davies, J.R.R. Tolkien Encyclopedia: Scholarship and Critical Assessment, p 682. Carson, H.M. "'Roman Catholicism.' In The New International Dictionary of the Christian Church, edited by J.D. Douglas et al., 853-56. Grand Rapids, MI: Zondervan 1978.

${ }^{x 1}$ The Holy Quran, Sourate Āli- Imrān, 42, 43, 44

${ }^{x l i}$ Pearce, Joseph. "Christ”. J.R.R. Tolkien Encyclopedia: Scholarship and Critical Assessment, Ed. Michael D.C. Drout. New York/London: Routledge, 2007, P 133-34.

xlii Pearce, Joseph. "Incarnation”. J.R.R. Tolkien Encyclopedia: Scholarship and Critical Assessment, Ed. Michael D.C. Drout. New York/London: Routledge, 2007. 207.

Caldecott, Stratford. Secret Fire: The Spiritual Vision of J. R. R. Tolkien. London: Darton, Longman \& Todd, 2003. Pearce, Joseph, ed. Tolkien: A Celebration. London: HarperCollins,

1999.

xliii Shippey, T.A. (2005 [1982]), The Road to Middle-earth, 3rd ed., P 110. Also on his Author of the Century, P 141. "Incarnation," in Drout, Encyclopedia, 293-94. Kerry, Paul E, editions. The Ring and the Cross Christianity and the Writings of J.R.R. Tolkien, UK: Fairleigh Dickinson University Press, 2011.

${ }^{\text {xliv }}$ Bradley j. birzer. "Catholicism, Roman”. J.R.R. Tolkien Encyclopedia: Scholarship and Critical Assessment, Ed. Michael D.C. Drout. New York/London: Routledge, 2007. 207-8

xlv Tolkien writes: "...Only one thing I [Ilúvatar] have added, the fire that giveth Life and Reality, and behold, the secret fire burnt at the heart of the world. Tolkien, C. (editor), The Book of Lost Tales 1, p. 53. Caldecott, Stratford. Secret Fire: The Spiritual Vision of J.R.R. Tolkien

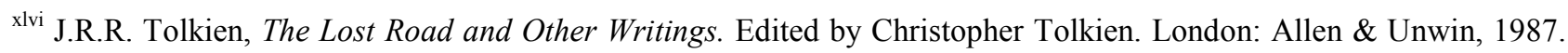
pp. 274,278

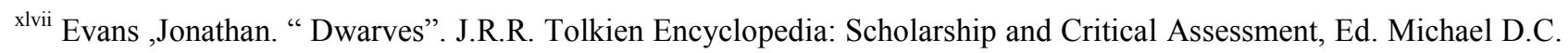
Drout. New York/London: Routledge, 2007, 171-172

xlviii Splintered Light: Logos and Language in Tolkien's World (revised edition), 2002. http://jonathansmcintosh.wordpress.com/2011/10/27/the-dwarves-tolkiens-ishmael/

${ }^{\text {xlix }}$ The Secret Fire and Iluvatar's Music by Philip R.

http://tolkienmedievalandmodern.blogspot.com/2011/04/secret-fire-and-iluvatars-music.html

${ }^{1}$ J. Birzer Bradley, J.R.R. Tolkien Encyclopedia: Scholarship and Critical Assessment, p 207 The nature of the Second Person of the Trinity, the Logos, appears only in the abstract in the story "Athrabeth Finrod Ah Andreth." Finrod and Andreth's conversation, though, does anticipate the Incarnation. "They say that the One will himself enter into Arda, and heal Men and all the Marring from the beginning to the end," Andreth skeptically states. "Even if He in Himself were to enter in," Finrod answers, "He must still remain also as He is: the Author without."

${ }^{\text {li }}$ Tolkien, J.R.R. The Lord of the Rings. Fiftieth anniversary edition. Boston: Houghton Mifflin, 2004.: The Fellowship of the Ring, Book 2, Chapter V, p. 322

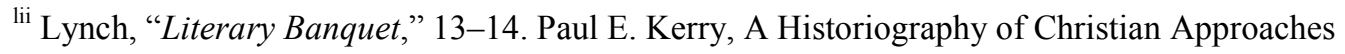

to Tolkien's The Lord of the Rings.

Kerry, Paul E, ed. The Ring and the Cross Christianity and the Writings of J.R.R. Tolkien, UK: Fairleigh Dickinson University Press, 2011. 43.

liii S. Caldecott, "Over the Chasm of Fire," P 29. Kerry, Paul E, ed. The Ring and the Cross Christianity and the Writings of J.R.R. Tolkien, UK: Fairleigh Dickinson University Press, 2011.

liv Chausse, "Icons of Jesus Christ," 30-32. Kerry, Paul E, ed. The Ring and the Cross Christianity and the Writings of J.R.R. Tolkien, UK: Fairleigh Dickinson University Press, 2011.

lv Tolkien wrote that in 1965. 
${ }^{\text {lvi }}$ Tolkien to Robert Murray, December 2, 1953, in ibid. 172, emphasis added.

lvii Pearce, Joseph, ed. Tolkien: A Celebration. London: HarperCollins, 1999.

Tolkien: Man and Myth. London: HarperCollins, 1998.

Caldecott, Stratford. Secret Fire: The Spiritual Vision of J.R.R. Tolkien. London: Darton, Longman \& Todd, 2003.

Birzer, Bradley J. J.R.R. Tolkien's Sanctifying Myth. Wilmington, DE: ISI Books, 2002.

Pearce, Joseph. "Incarnation". J.R.R. Tolkien Encyclopedia: Scholarship and Critical Assessment, Ed. Michael D.C. Drout. New York/London: Routledge, 2007, 329

lviii Pearce, Joseph. "Christ”. J.R.R. Tolkien Encyclopedia: Scholarship and Critical Assessment, Ed. Michael D.C. Drout. New York/London: Routledge, 2007,P 133-34

Caldecott, Stratford. Secret Fire: The Spiritual Vision of J. R. R. Tolkien. London: Darton, Longman \& Todd, 2003.

${ }^{\text {lix }}$ Boyle, Sacred and Secular, 256. Paul E. Kerry, A Historiography of Christian Approaches

to Tolkien's The Lord of the Rings

${ }^{1 x}$ C.S. Lewis quoted in Tolkien, Lays of Beleriand, 151. Birzer, Tolkien's Sanctifying Myth, 74 